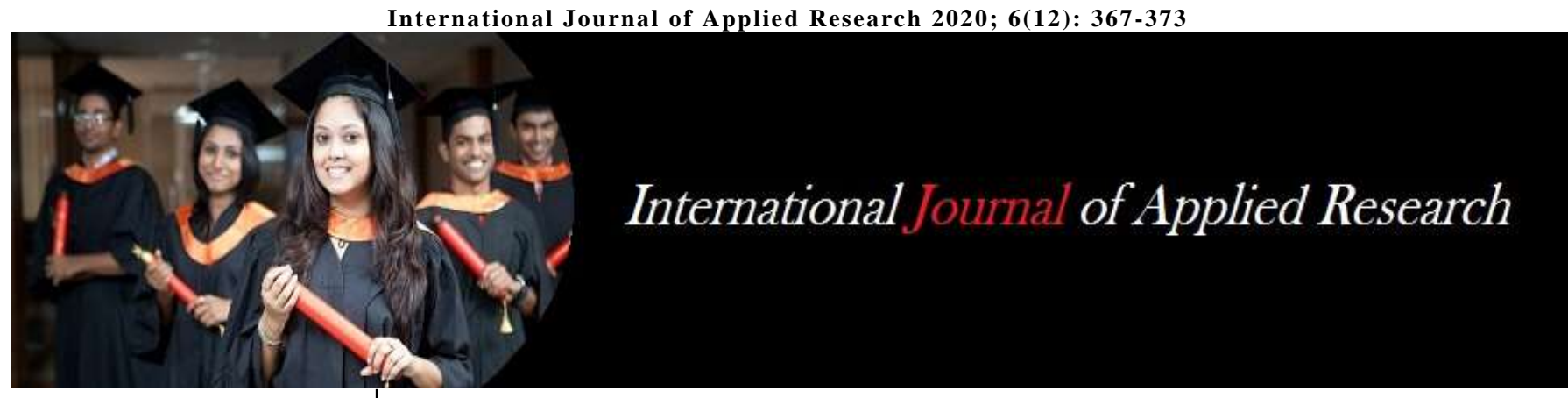

ISSN Print: 2394-7500

ISSN Online: 2394-5869

Impact Factor: 8.4

IJAR 2020; 6(12): 367-373

www.allresearchjournal.com

Received: 25-10-2020

Accepted: 29-11-2020

Bakhtaver Hassan

Visiting Faculty, Amity School

of Economics, Research

Scholar, Amity University,

Noida, Uttar Pradesh, India

Dr. Mahua Bhattacharjee

Professor, Amity School of

Economics, Amity University,

Noida, Uttar Pradesh, India

Dr. Shabir Wani

Head of Department, Agri-

Business and Horti-

Management, SKUAST-K,

Srinagar, Jammu and

Kashmir, India

\section{Value-chain analysis of horticultural crops-regional analysis in Indian horticultural scenario}

\author{
Bakhtaver Hassan, Dr. Mahua Bhattacharjee and Dr. Shabir Wani
}

\author{
DOI: https://doi.org/10.22271/allresearch.2020.v6.i12f.8122
}

\begin{abstract}
Value chain encompasses full range of activities from the production, distribution, processing, transporting and value addition, finally to the end consumer. Value chain analysis enables us to understand the various players involved, various activities which add value to the product and also the efficacy of the chain. In Horticultural sector in India, value chain analysis provides us an opportunity to map the chain, locate the actors involved as well as understand the different challenges in the movement of the product from the producers to the consumers. The agri-climatic diversity of India presents varied opportunities in terms of production as well as distribution of the horticultural crops. We tried to analyze three main regions, North West Himalayan region which comprises of Jammu and Kashmir, Uttarakhand and Himachal Pradesh, North East Region comprising of Assam, Sikkim and six other sister states and Performer states whose area under horticulture and production of horticulture is significant. Based on the current production, area and productivity we analyzed the area and the value chain in each of the region. While the production among the big Performer states was significant for the total horticultural sector, there were issues in the value chain efficiency. Like the fertilizer and pesticide use was unscientific, credit supplies to the farmer wasn't also effective. High perishability and lower marketing infrastructural capacity affected the overall progress of the sector in the region. In the North West and North East Himalayan States, poor connectivity, high terrain and low infrastructural development of the markets were the common obstacles for the growth and development of the sector. In the North East region contributing $4.5 \%$ of the horticultural produce, the Jhum Cultivation and lack of technological development have proven to be major roadblocks in the sector. Lack of marketing opportunities, inadequate processing centers at the primary and secondary centers impact the value of the produce. This lowers down the total remuneration accrued to the farmers. Proper infrastructural development like road connectivity, communication networking and adequate agricultural information dissemination at regular intervals is critical for better productivity and production of the horticultural crops in the region. Overall, value chain analysis helps us understand to the problems at each level of the production, value addition and transportation. With diverse agri-climatic regions, we have different challenges which need a bottom-up regional approach for effective development. This is in consonance with the recent launch of "One District, One Product" of Horticulture in the recent Budget, 2020-21.
\end{abstract}

Keywords: Value chain analysis, north east region, North West Himalayas, production, acreage, value addition

\section{Introduction}

Food and Agriculture Organisation defines value chain as "A value chain can be defined as the full range of activities which are required to bring a product or service from conception, through the different phases of production (involving a combination of physical transformation and the input of various producer services), delivery to final customers, and final disposal after use."

Value Chain Analysis enables us to track the movement of a specific product through the value chain involving different actors who add value to the product in both monetary and quality terms. In a specific value chain, multiple chain actors help in transacting a product which includes input dealers, producers which are farmers in this context, marketing agencies or agents, processing agencies, transporters, wholesale agents and finally to the retailer and consumer.

In understanding the value chain of the horticultural sector in India, the activities are split into primary and support activities. While primary activities are mostly related to production, the support activities provide necessary cushion in terms of bringing efficiency and
Corresponding Author: Bakhtaver Hassan

Visiting Faculty, Amity School of Economics, Research

Scholar, Amity University,

Noida, Uttar Pradesh. India 
effectiveness in the production chain, such as human resource management or technological development.

Horticultural sector in India has predominantly been a primary sector activity in India so far. While the horticulture development has seen a radical shift from past few decades, there is substantial gap between the potential and the actual production of the sector. Value chain analysis of the sector across the different agri-climatic regions presents an opportunity to understand the real dynamics involved in the movement of the horticultural products across the chain. This also presents us the opportunity to understand the need for integrated value chain in the sector across the regions.
While the horticultural sector is critical for Indian agricultural growth overall, we will try to analyze the importance of value chain in the sector.

Value chain analysis in horticulture, therefore is significantly important in understanding the regional growth of the sector in terms of both value of output of the horticultural crops, their marketing in the changing urbanrural landscape. Understanding the opportunities and challenges in the sector across the regions would bring clarity in providing region-specific endogenous growth in the sector.

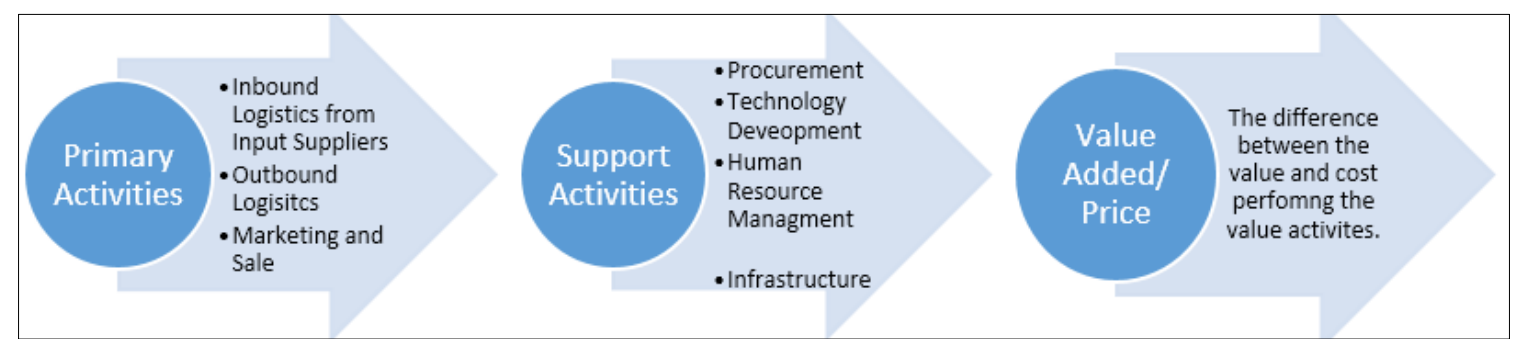

Fig 1: Value Chain Actors and the Framework of the Activities.

\section{Overview of the horticulture sector in India}

Horticulture attains critical importance in the agricultural landscape of India. The growing population, falling farm income and rising farm distress all point to diversification of agriculture in India. This makes even more sense from the ecological as well as financial point of view. With growing clamour of climate change bringing dynamic challenges in the agricultural landscape and the consequent fall of production and hence income levels, horticultural sector is considered an important driver of rural and regional development. The increase in the demand generated by the rise in income among the population is in consonance with the changing dietary habits in the urban landscape of the country.

India is infect one of the largest producers of horticultural crops in the world and infect only behind China in fruits and vegetables. The horticultural growth in the past few years has been significant and even surpassed the overall production of the food-grains. According to Economic Survey, 2018-19 horticulture sector contributes 33\% to the total agricultural GDP of the country in terms of total output. The importance of horticulture in meeting the challenges of the present day world is hardly overemphasized. It is critical in improving the productivity of the land, generating employment, ameliorating poverty amongst the farmers and improving the exports. Above all, it is important in providing nutritional security to the population. Growth of Horticultural Sector in India has been a predominant green shoot in the agricultural economy of the country. With high growth potential of the sector across regions, it is likely to be the "go-to sector" and infact the sunrise sector of our economy.

Table 1: Percentage Share of Horticulture Output in Agriculture

\begin{tabular}{|c|c|c|c|c|c|}
\hline Year & $\mathbf{2 0 1 1 - 1 2}$ & $\mathbf{2 0 1 2}-13$ & $\mathbf{2 0 1 3 - 1 4}$ & $\mathbf{2 0 1 4 - 1 5}$ & $\mathbf{2 0 1 5 - 1 6}$ \\
\hline Fruits & $22.3 \%$ & $23.3 \%$ & $21.3 \%$ & $24.8 \%$ & $25.9 \%$ \\
\hline Condiments & $3.2 \%$ & $3.1 \%$ & $3.3 \%$ & $3.6 \%$ & $3.5 \%$ \\
\hline Plantation & $1.5 \%$ & $1.4 \%$ & $1.4 \%$ & $1.4 \%$ & $1.6 \%$ \\
\hline Total Horticulture & $29.2 \%$ & $30.0 \%$ & $30.1 \%$ & $32.0 \%$ & $33.3 \%$ \\
\hline
\end{tabular}

Source: Horticulture at a Glance, 2018, Ministry of Statistics,

Planning and Implementation.
The erstwhile Planning Commission of India has divided Indian landscape into 15 major agro-climatic zones to provide for Agricultural Regional Planning Development in the country. This attains significance with the recently launched "One District- One Product" in Horticulture in Budget 2020-21. The Agri-climate zones provide varied possibilities for the development of agriculture and horticulture in particular.

So far, with the current data. Horticultural Development across states has been varied and divergent. Recognizing the horticultural significance as a multiplier effect, several states like Maharashtra, Gujarat, Karnataka, Andhra Pradesh, Kerala, Punjab, Tamil Nadu, Haryana and Rajasthan diversifying their cropping pattern in favour of these horticultural crops.

\section{Literature review}

GL Kaul (1996) ${ }^{[6]}$ has suggested for diversification of cropping pattern and an average of double digit growth in horticultural sector to ensure that farm income alongwith the nutritional security of the population is met. Horticulture provides a major driver of agricultural growth with it high input to output ratio. Further, the lack of proper marketing channel and inadequate farmers' knowledge impede the growth of the sector in the potential areas where unsustainable agricultural practices are in vogue.

Lakshman Chandra De (2017) has analyzed the potential of the horticultural sector in the North-Eastern Region. The region has immense potential for both vertical as well as horizontal horticultural growth as only $18 \%$ of the total cultivable area falls under horticulture sector. Proper planning and utilization of resources would provide a necessary push to infuse horticultural growth in the region. Kumar et al. (2012) ${ }^{[9]}$ analyzed the input cost for cultivation of commercial crops in Himachal Pradesh. According to their study, the farmers' share was just $20 \%$ of the total price fetched in the market which pointed out to two significant factors. One, input cost of the commercial crops was high due to improper knowledge regarding fertilizer utilizer and high human labour cost. Two, the marketing was poor which created high price wedge in the sector. They 
suggested that the farmer needs to educate about the proper chemical application for better productivity while maintaining the character of soil intact. This would also ensure that the input cost stays within the limits for better remuneration.

Kirve et al. (2002) [5] investigated that high commission charges and large number of intermediaries in the value chain remained a major constraint in providing an efficient marketing of fresh vegetables in the western part of Maharashtra. Lal and Sharma (2004) ${ }^{[8]}$ brought forward a major impediment in the economics of the cultivation of horticultural crops, especially vegetables in Himachal Pradesh. In absence of proper marketing channel, due to poor infrastructural connectivity and a near monopoly in the respective mandis, the farmers got just one fourth of the total price that the end consumer pays.

Collins (2003) ${ }^{[4]}$ presented a significant case study of Australian horticultural sector whereby, the development of efficient value chain helped not only develop trust amongst the consumers but also integrated the chain management for effective development of the sector. Singh et al. (2009) ${ }^{[10]}$ analyzed the challenges of the horticultural supply chain through estimation of marketing costs and margins. The study focused primarily on the marketing barriers such as commission agents, high number of intermediaries, poor processing and inadequate marketing knowledge of the farmers which restricted the flow of actual remuneration to the farmers.

\section{Data and methodology}

The study required in-depth understanding of the product flow, its treatment at each level of the chain, price and value addition and roles played by each player in the chain. Both quantitative and qualitative assessment for comprehensive analysis is done to provide a clear picture throughout the different regions of the country.

Data from National Horticulture Board, Ministry of Statistics Planning and Implementation- MOSP- and Agricultural Processing and Export Development Agency APEDA was collected to ascertain the current regime. Alongwith it, data from Horticulture Department Jammu and Kashmir, AGMARKNET, DoNER- Ministry of Development of North Eastern Region and other state respective departments was assessed to help in understanding the current scenario from production to marketing. This also helped us to understand the gap in reaching the real potential of the horticulture crops in different regions.

\section{Objective of the study}

- To provide a regional as well as systematic analysis of the present value chain in the country in terms of price and journey of the material from production, trading, marketing and ultimately to the end consumer.

- To identify the present infrastructure availability in the assessment of horticultural development of the country.

- To provide the futuristic view for enhancing value chain efficiency of the horticultural products in the country.

\section{Results and discussion \\ North west Himalayas- immense potential, high growth and infrastructural inadequacy}

Favourable agri-climatic conditions and a historical connection with Horticulture in the three North-West states, Himachal Pradesh, Uttarakhand and Union Territory of Jammuand Kashmir have consistently pushed for upswing in the acreage and production of horticulture crops in the region. The area under horticulture has increased manifolds from 173.63(000) hectares in 2000-01 to 325.63 (000) hectares in 2016-17. While productivity of most of the temperate fruits grown in the region is higher than the national average, the erstwhile state of Jammu and Kashmir fares far better than the rest of the two in this respect. Infact the productivity is nearly 21 tonnes per hectares which is comparable to most of the technologically advanced European countries.

Falling productivity in Himachal Pradesh on account of impact of climate change and high utilization of chemical fertilizers is already creating pressure on the farmers. But there are common challenges like inadequate information dissemination to the farmers, lack of proper forecasting mechanism for timely coverage of the crops and poor packaging in the post-harvesting which reduce the total remuneration of the producer. Bigger challenge is the marketing of the horticultural product, which is characterized by transport inadequacy that runs inefficiently in the distribution channel. Poor marketing information amongst the farmers, lack of proper connectivity, rough roads and high number of intermediaries further render the distribution channel inefficient. There is widening gap between the farm-gate prices and the price at which consumers get their product as the intermediaries primarily earn the most in the distribution channel. Around 30\% of the horticultural produce is marketed through ProducerCommission Agent- Wholesaler- Retailer- Consumer (P-AW-R-C) which is considered as one of the inefficient supply chains in horticultural marketing (Dastagiri)

Table 2: Agro-climatic zones with regional constraints in lieu of Horticulture Sector.

\begin{tabular}{|c|c|c|}
\hline Agro-Climatic Region & States / Parts of States & Region Specific Constraints \\
\hline Western Himalayan Region-I & J \& K, H.P., Uttarakhand & $\begin{array}{c}\text { Severe soil erosion, soil degradation due to heavy precipitation and } \\
\text { excessive deforestation. Low Seed Replacement Ratio. Poor road } \\
\text { connectivity and inadequate marketing infrastructure. }\end{array}$ \\
\hline $\begin{array}{c}\text { Eastern Himalayan Region-II } \\
\text { Astidic Soil, Soil erosion and floods, shifting cultivation-Jhum } \\
\text { Cultivation. Low SRRs, non-availability of electricity, poor road } \\
\text { connectivity, poor input delivery system and poor marketing } \\
\text { infrastructure. }\end{array}$ \\
\hline $\begin{array}{c}\text { Lower and Middle Gangetic } \\
\text { Plains Regions-III \& IV }\end{array}$ & West Bengal, Bihar, Eastern UP & $\begin{array}{c}\text { Flood, improper drainage, Salinity of soil, Arsenic contamination, } \\
\text { high population growth, poor infrastructure and inadequate } \\
\text { communication. }\end{array}$ \\
\hline $\begin{array}{c}\text { Upper and Trans-gangetic Plains } \\
\text { Region-V \& VI }\end{array}$ & Western U.P., Punjab, Haryana & $\begin{array}{c}\text { Groundwater depletion, decreasing total factor productivity, } \\
\text { micronutrient deficiency, food-grain obsession - MSP Driven. }\end{array}$ \\
\hline \multicolumn{2}{|c}{$\sim 369 \sim$}
\end{tabular}




\begin{tabular}{|c|c|c|}
\hline $\begin{array}{c}\text { Eastern Plateau \& Hills Region- } \\
\text { VII }\end{array}$ & Orissa, Jharkhand, Chhattisgarh & $\begin{array}{c}\text { Moisture stress, drought and Soil acidity, Iron toxicity, low SRRs, } \\
\text { non-availability of electricity, high population growth, poor } \\
\text { communication and flooding on the Eastern Side. }\end{array}$ \\
\hline $\begin{array}{c}\text { Central, Western and Southern } \\
\text { Plateau and Hills Regions-VIII, } \\
\text { IX \& X. }\end{array}$ & $\begin{array}{c}\text { Bundelkhand (in U.P \& MP), parts } \\
\text { of Rajasthan, Maharashtra, AP, } \\
\text { Karnataka \& Tamil Nadu }\end{array}$ & $\begin{array}{c}\text { Drought, moisture stress, Soil crusting and cracking, poor marketing } \\
\text { intelligence and inadequate farm knowledge. }\end{array}$ \\
\hline $\begin{array}{c}\text { East \& West Coast Plains \& } \\
\text { Ghats Region-XI \& XII. }\end{array}$ & $\begin{array}{c}\text { Pondicherry, Coastal area of Orissa, } \\
\text { AP, TN and Kerala, Goa, parts of } \\
\text { Karnataka \& Maharashtra }\end{array}$ & $\begin{array}{c}\text { Poor soil conditions, improper irrigation facilities and high } \\
\text { degradation of arable land. Fast encroachment and poor agricultural } \\
\text { extension services. }\end{array}$ \\
\hline $\begin{array}{c}\text { Gujarat Plains \& Hills \& } \\
\text { Western Dry Region Regions- } \\
\text { XIII \&XIV }\end{array}$ & $\begin{array}{c}\text { Gujarat, D\&N Haveli, Daman \& } \\
\text { Diu, North Western Rajasthan }\end{array}$ & $\begin{array}{c}\text { Aridity, Frequent drought, moisture stress poor soil, habitation of } \\
\text { desert }\end{array}$ \\
\hline The Islands Region-XV & Andaman \& Nicobar, Lakshadweep & $\begin{array}{c}\text { High soil acidity- laterite soil, inadequate infrastructural development. } \\
\text { Frequent Cyclone. High Susceptibility to Climate Change. }\end{array}$ \\
\hline
\end{tabular}

Source: NITI Aayog (erstwhile Planning Commission)

\section{North-eastern region-the pristine horticulture zone but still under-utilized}

North-Eastern Region is infact the most diverse and ecologically fragile area of the country. With high percentage, nearly $60 \%$ of the total land under forests the region has scope for productive horticulture sector. Infact, NITI Aayog in the Three Year Agenda has clearly mentioned about the role of horticulture sector in bringing much needed comprehensive development in the region. The total area under horticultural crops in the region is around $851.5(000)$ hectares which is nearly $3.2 \%$ of the total geographical region in the region. Geographically, the region is characterized by mountainous regime, difficult terrain and dense forests with maritime tropical forests, temperate and alpine vegetation. Slash and burn cultivation, prominently known as Jhum cultivation is practiced commonly which is a serious impediment to the ecological development of the region. However, this diversity in theagri-climatic conditions in the region offers scope for cultivation of different horticultural crops.

While the region contributes nearly $4.6 \%$ to the total horticultural output of the country, only $0.84 \%$ of the total cold storage facilities are located in the region which accommodates just $0.65 \%$ of the total capacity of the cold storage in the country. As such there is high perishability of the horticultural crops from the region. Further, the region is connected via the narrow $22 \mathrm{~km}$ wide Chicken's neckSiliguri Corridor with the country, restricting its connectivity with the mainland.

Within the region the ethnic and cultural diversities along with the mountainous terrain poses significant barrier in terms of connectivity which hampers the marketing potential of the horticultural crops from the region. The infrastructural availability in the region is inadequate, minimum cold-storages, poor marketing at the local levels alongwith lack of food-processing industries render high wastage and poor remuneration to the producer.

\section{Performers- are they?}

Bigger states within the mainland which took a lead in the agricultural diversification early on have been the major drivers of the horticultural development in the country. Among the states, Punjab, Gujarat, Maharashtra, Karnataka, Andhra Pradesh and Tamil Nadu are major horticultural cultivating states in the country. Nearly $65-70 \%$ of the current production comes from these states. In Punjab, the onset of contract farming has carved a niche of its own by providing a direct contact of the farmers to the actual end company. Similarly, Gujarat with the favourable climate and infrastructural development has also been fortunate to present itself as a major horticultural state in the country.

Regional bias as well bias against few horticultural crops has surprisingly ensured that these bigger states retain the major horticultural crop-producers of the country. Adequate irrigation and warehouse facilities in Punjab has enabled the farmers to switch to potato and tomato as a prominent horticultural crop. Another element is the priority for TOP crops- Tomato, Onion and Potato in these states. While there is no denial that the cultivation of these crops is essential for the farmer welfare as well for the nutritional and food security of the nation. The bias towards these crops has been at the expense of other horticultural crops. Nearly 97\% of the cold storage infrastructure facilities has been used by these three TOP crops.

Other issues like on the production front, most of the state's lack technical know-how, as the agricultural extension services are still a non-starter even in these regions. Nearly $62 \%$ of the producers receive low quality seedlings which affect the overall plant health and hence lowers the productivity of the crop. Another peculiar issue in these states is the over-usage of low quality pesticides which impact the overall health of the soil as well as the productivity of the crop. In some areas of Punjab, Karnataka infestation is common which may reduce the total yield upto $30 \%$.

On the marketing front, lack of market information among the farmers is another major problem impacting the sector. Price of the horticultural product abruptly changes with the arrival of new horticultural products in the market which impacts the small and marginal farmers the most. Grading, packaging and transportation cost among the small and marginal farmers is also a major constraint and as such often they fail to sell their meagre quantity in the market. Infrastructural availability is good compared to the North West Himalayan and North East Region, but lack of proper cold storages at the block level amasses high perishability in these states.

\section{Comparative analysis}

While there has been considerable progress in production and acreage increment in the bigger states which we have termed as performer states due to their early start. The North West Himalayan States are catching up in time. The production and the acreage in these states speak highly about the potentialities as well as the current status of the horticultural sector in the region. 
Table 3: Production of North West Himalayan States

\begin{tabular}{|c|c|c|c|c|c|}
\hline States & $\mathbf{2 0 1 3 - 1 4}$ & $\mathbf{2 0 1 4 - 1 5}$ & $\mathbf{2 0 1 5}-16$ & $\mathbf{2 0 1 6 - 1 7}$ & $\mathbf{2 0 1 7 - 1 8}$ \\
\hline Jammu and Kashmir & 2073.94 & 1779.4 & 2115.52 & 2241.06 & 2355.19 \\
\hline Himachal Pradesh & 896.04 & 898.08 & 961.19 & 1047.97 & 1081.69 \\
\hline Uttarakhand & 678.49 & 785.97 & 659.1 & 662.1 & 669.94 \\
\hline TOTAL & 3648.47 & 3463.45 & 3735.81 & 3951.13 & 4106.82 \\
\hline
\end{tabular}

Table 3, above tells us that in the past five years there has been consistent growth of horticultural sector in the North West Himalayan Region. While the productivity of Jammu and Kashmir has been comparable to the Western Countries in Apple cropparticularly, it is still low in other crops as well as in other states in the region. The region has seen considerable progress in the basic horticultural development which is slowly bringing a paradigm shift in horticultural in the region.

Table 4: Production of Performer States.

\begin{tabular}{|c|c|c|c|c|c|}
\hline States & $\mathbf{2 0 1 3 - 1 4}$ & $\mathbf{2 0 1 4 - 1 5}$ & $\mathbf{2 0 1 5 - 1 6}$ & $\mathbf{2 0 1 6 - 1 7}$ & $\mathbf{2 0 1 7 - 1 8}$ \\
\hline Andhra Pradesh & 10510.56 & 9121.62 & 10088.82 & 13612.92 & 15215.85 \\
\hline Karnataka & 6652.42 & 6799.89 & 7023.69 & 7218.38 & 7133.94 \\
\hline Gujarat & 8001.96 & 8300.6 & 8477.17 & 8937.42 & 8996.82 \\
\hline Maharashtra & 13457.92 & 11089.53 & 9749.8 & 10630.08 & 11728.66 \\
\hline Madhya Pradesh & 5696 & 6119 & 5783.06 & 6935.6 & 7416.91 \\
\hline West Bengal & 2909.71 & 3313.7 & 3516.71 & 3585.3 & 3850.56 \\
\hline Punjab & 1541.24 & 1644.5 & 1790.94 & 1818.19 & 1908.85 \\
\hline Uttar Pradesh & 6887 & 7558.99 & 10296.76 & 10302.76 & 10539.78 \\
\hline Total & 55656.81 & 53947.83 & 56726.95 & 63040.65 & 66791.37 \\
\hline
\end{tabular}

In the above table, the performer state as we call them are major producers of horticultural crop in the country

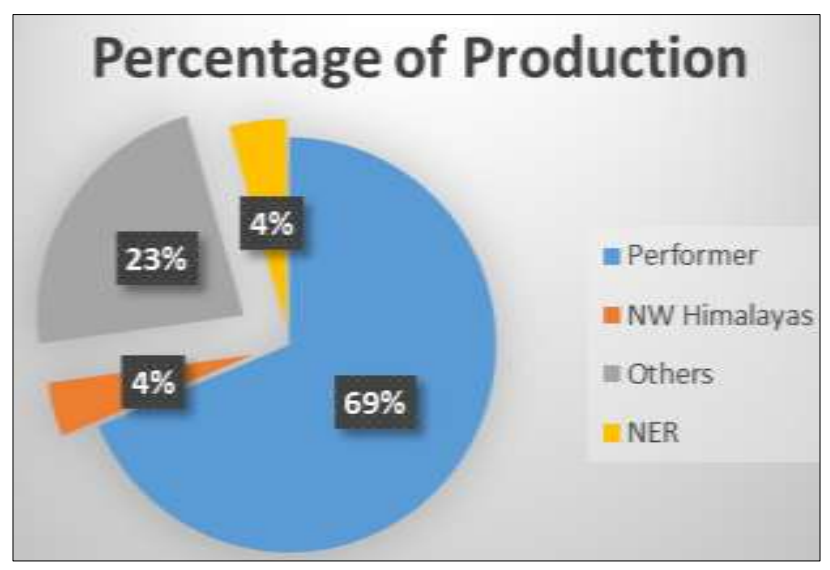

Fig 2: Percentage of Production and Area of the States- Comparative Analysis

Figure 3, explains that the performer states contribute $68 \%$ of the production of horticulture. The corresponding acreage from the states is around $78 \%$, this points out to mainly two formidable points. One, that these states are too-big and indispensable for our horticulture sector both from the point of view of area as well as from production point of view. Second that the productivity in these states is low and not in sync with the total acreage under horticulture. These observations push us back to consider the North West and North East Himalayan states.

The Himalayan states presently do not conform to the international standards in terms of productivity. But they present ecologically sustainable means to attain the current level of production from the given acreage in these regions. While the erstwhile state of Jammu and Kashmir has attained high growth and production in Apple, there are contributing almost $60 \%$ of the total horticultural produce in the last few years. Alongwith these states have also been the major drivers of change in diversification of agriculture which suits the current climate change situation. While fruits and vegetables are majorly grown in these states based on their agri-climate suitability. Maharashtra and Andhra Pradesh owing to large acreage under horticulture and also to the varied climatic conditions within, contribute almost $40 \%$ of the total produce from these states.

Table 5: Production in North East Region

\begin{tabular}{|c|c|c|c|c|c|}
\hline States & $\mathbf{2 0 1 3 - 1 4}$ & $\mathbf{2 0 1 4 - 1 5}$ & $\mathbf{2 0 1 5 - 1 6}$ & $\mathbf{2 0 1 6 - 1 7}$ & $\mathbf{2 0 1 7 - 1 8}$ \\
\hline Assam & 2007.8 & 2030.14 & 2077.77 & 2024.84 & 2123.62 \\
\hline Arunachal Pradesh & 321.27 & 331.4 & 306.27 & 124.38 & 125.7 \\
\hline Sikkim & 24.05 & 0.03 & 23.48 & 25.55 & 54.89 \\
\hline Mizoram & 343.9 & 350 & 330.41 & 339.2 & 340.5 \\
\hline Manipur & 515.69 & 521.57 & 467.76 & 478.77 & 455.69 \\
\hline Nagaland & 411 & 411.63 & 378.23 & 388.23 & 380.42 \\
\hline Meghalaya & 348.8 & 377.25 & 395.4 & 426.86 & 316.81 \\
\hline Tripura & 786.15 & 819.12 & 854.12 & 559.32 & 547.52 \\
\hline Total & 4758.66 & 4841.14 & 4833.44 & 4367.15 & 4345.15 \\
\hline
\end{tabular}

North Eastern Region is biodiversity rich area with nearly $10.5 \%$ of the total country's area and contributing $3.8 \%$ to the horticultural area of the country. High endemism and diverse climatic conditions does present a significant opportunity to grow horticultural crops in the region. Assam contributes $50 \%$ of the total horticultural production in the region. The four sisters- Nagaland, Meghalaya, Mizoram and Manipur present similar opportunities as well as contribute almost equally to the horticultural produce.

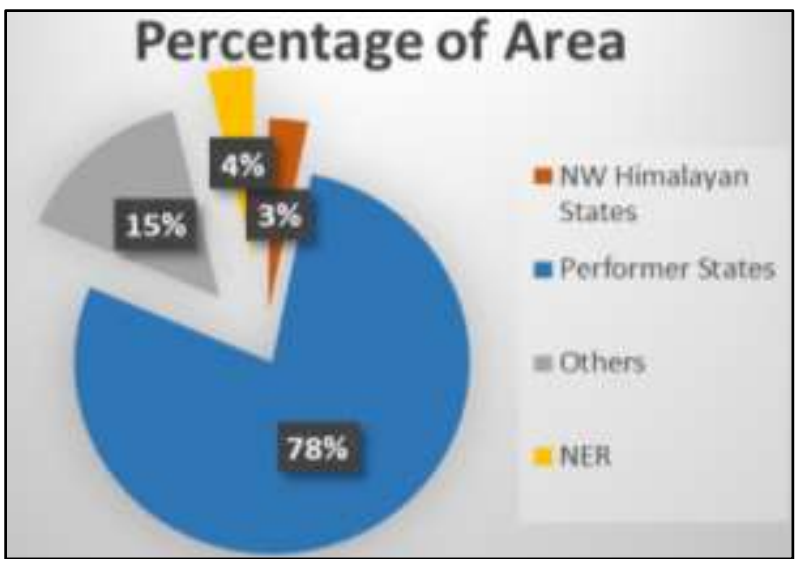

certain issues. One, there is falling productivity as well as production of saffron in the area. Second, walnut productivity and acreage is also going down which is worrisome, considering that nearly $90 \%$ of the walnut production and export is from the Union Territory. In the states of Uttarakhand and Himachal Pradesh, there is high deforestation and low incentive for shifting acreage from agriculture to horticulture practices. Also, the productivity of the horticultural crops is not upto the standard which provides lower returns to the farmers, traders as well as affects the overall quality of the horticultural produce.

The North-Eastern Region also presents different challenges in terms of production and acreage. The Jhum Cultivation is a formidable challenge in almost all of these states, it constantly deteriorates the natural growth cycle of the forests while real increment in acreage along sustainable 
lines is not seen in these states. The productivity in the horticultural sector is equally low as compared to the North Western Himalayan Region. However, endemism, rich biodiversity and varied agri-climatic conditions present significant opportunity for the region to outpace other horticultural regions of the country.

Table 6: Cold Storage Infrastructure with Capacity in Different States.

\begin{tabular}{|c|c|c|c|}
\hline No & Name of the State & Number of Cold Storages & Capacity (Mts) \\
\hline 1. & Assam & 37 & 163258 \\
\hline 2. & Andhra Pradesh and Telangana & 452 & 1836366 \\
\hline 3. & Arunachal Pradesh & 2 & 6000 \\
\hline 4. & Bihar & 167 & 353463 \\
\hline 5. & Chhattisgarh & 98 & 4842331 \\
\hline 6. & Delhi & 97 & 129857 \\
\hline 7. & Gujarat & 890 & 3515976 \\
\hline 8. & Haryana & 352 & 791780 \\
\hline 9. & Himachal Pradesh & 65 & 126967 \\
\hline 10. & Jammu and Kashmir & 55 & 182527 \\
\hline 11. & Jharkhand & 58 & 236680 \\
\hline 12. & Karnataka & 209 & 602457 \\
\hline 13. & Kerala & 199 & 81705 \\
\hline 14. & Madhya Pradesh & 302 & 1281411 \\
\hline 15. & Maharashtra & 604 & 979607 \\
\hline 16. & Manipur & 3 & 7100 \\
\hline 17. & Meghalaya & 4 & 8300 \\
\hline 18. & Mizoram & 3 & 3971 \\
\hline 19. & Nagaland & 4 & 7350 \\
\hline 20. & Orissa & 177 & 566321 \\
\hline 21. & Punjab & 672 & 2201386 \\
\hline 22. & Rajasthan & 167 & 561293 \\
\hline 23. & Sikkim & 2 & 2100 \\
\hline 24. & Tamil Nadu & 173 & 347583 \\
\hline 25. & Tripura & 14 & 45477 \\
\hline 26. & Uttar Pradesh & 2368 & 14500773 \\
\hline 27. & Uttarakhand & 47 & 162821 \\
\hline 28. & West Bengal & 511 & 5940511 \\
\hline & TOTAL & 7916 & 36229675 \\
\hline
\end{tabular}

Source: Horticulture at a Glance, 2018. Ministry of Statistics, Planning and Implementation

Table 6, clearly depicts the infrastructural bias in the horticultural sector. The performer states have $92 \%$ of the total cold storage of the country. Nearly $97 \%$ of the total horticultural produce from these states directly goes to the cold-storage. However, there is another inherent bias in the horticultural classification while using this mechanism. The TOP-Tomato, Onion and Potato share almost $97-98 \%$ of the total cold storages of the country leaving meagre for the other horticultural crops. This brings out high perishability and wastage into the picture which amounts to nearly 23000 crores annually. Lack of proper infrastructure and timely intervention in the hilly states especially creates hurdles in procurement which impacts the farmer remuneration, hence discouraging farmers to shift to horticultural crops in the region.

\section{Conclusion}

Horticulture sector is highly input-intensive in nature. Proper knowledge to the farmers, adequate input supplies at proper times, better credit facilities and timely information dissemination is critical for bettering the productivity and production of the sector.

In erstwhile state of Jammu Kashmir, Uttarakhand and Himachal Pradesh skilling of the farmers and development of Farmer Producer Organisation is critical for cluster development of the sector in the region. This includes, leveraging technology and providing cheap credit to these FPOs to create avenues of growth. The productivity is another critical factor which should be considered in the region. Focus on technological development, leveraging smart-technology and proper use of inputs at the farm level is equally important for sustainable development of the sector in the region.

While deforestation and lack of horticultural-industrial link is missing in NER, there needs a coordinated approach of the Tribal Districts, State Governments as well as DoNERMinistry for Development of North Eastern Region to provide the required infrastructural development in the region? Using region-specific horticultural products will create niche markets which would enhance the global value chain reputation of the country. In this regards, Horticulture Mission for North East and Himalayan States which is already in the market needs a revamp. This should be in line to enhance the value chain efficiency, in terms of development of processing centers for better grading and sorting at the primary level and then adequate value addition at the lateral stages for better remuneration. This includes development of the food-processing industries like the Jam and Pickle at the primary level to incentivize the farmers of the region. Development of cold-storage facilities and utilizing the capacity of the already existing cold-storage facilities to the fullest will also ensure that the market glut during the peak harvesting time is arrested. This would ensure that the farmer or trader extends the stocks of their produce till 8 months, thus giving them better bargaining power, hence better remuneration. Technological Advancement is also necessary in the post-harvest management. Use of Pack-House Concept and Controlled 
Atmosphere at the storage facilities is imperative to ensure that the quality of the produce is comparable to international standards.

In the performer states, the sale of quality seeds and regulated use of pesticide through Farmer Producer Organization should be encouraged. Introduction of crop insurance scheme which caters to the fundamentals of horticulture should be brought in to compensate the farmers, especially small and marginal farmers. Proper input supply of fertilizer according to the soil health should be adopted in letter and spirit to ensure there is minimum damage to the soil-characteristics of the region. The government has to prioritize according to the changing dynamics of the market as well the growing clamour of climate change. Subsequently, the MSP- Minimum Support Price in foodgrains should be considered while taking cognizance of the horticultural crops of the region, especially in states in Punjab, Haryana and Uttar Pradesh.

Value-addition in horticulture is complete when there is development of food-processing industries in each of the region. This entails a proper infrastructural development, proper road connectivity, logistics efficiency and direct link of the farm to the industry for efficient value addition. The momentum of the upsurge of horticultural sector cannot be sustained if we continue to delay the required amendments needed. Adequate connectivity, effective agricultural extension services, efficient utilization of input supplies, improved seed replacement ratio and proper development of marketing infrastructure is critical to enhance value chain efficiency of horticulture sector in the country.

\section{References}

1. Asati BS, Yadav DS. Diversity of horticultural crops in north eastern region. ENVIS Bulletin: Himalayan Ecology 2004;12(1):1.

2. Bhat TA, Choure T. Status and strength of apple industry in Jammu and Kashmir. International Journal of Research 2014;1(4):277-283.

3. Chand R, Raju SS, Pandey LM. Progress and potential of horticulture in India. Indian Journal of Agricultural Economics 2008,63,902-2016-67340.

4. Collins R. Supply chains in new and emerging fruit industries: the management of quality as a strategic tool. Acta Horticulturae 2003;604:75-84.

5. Kirve NV, Navdkar DS, Shette VR, Dorge JT. Production and marketing of french bean. Indian Journal of Agricultural Marketing 2002;16(2):59-63.

6. Kaul GL. Horticulture in India-production, marketing and processing. Indian Journal of Agricultural Economics 1997;52(3):561-573.

7. Sharma JC, Chaudhary SK. Vertical distribution of micronutrient cations in relation to soil characteristics in lower Shiwaliks of Solan district in North-West Himalayas. Journal of the Indian society of soil science 2007;55(1):40-44.

8. Lal H, Sharma KD, Thakur DS. Vegetable marketing in Himachal Pradesh: constraints and opportunities. The Bihar Journal of Agricultural Marketing 2000;8(4):416815.

9. Kumar S, Sharma A. Agricultural Value Chains in India: Prospects and Challenge. CUTS (Consumer Unity and Trust Society) International, Jaipur 2016,19.

10. Singh SP, Sikka BK, Singh A. Supply chain management and Indian fresh produce supply chain:
Opportunities and challenges. In: Proceedings of the $19^{\text {th }}$ Annual World Symposium, held at Budapest, Hungary, 20-23 June 2009. International Food \& Agribusiness Management Association, Hungary 2009. 